Article

\title{
Early and Dynamic Socio-Academic Variables Related to Dropout Intention: A Predictive Model Made during the Pandemic
}

\author{
Jorge Maluenda-Albornoz $^{1, *}$, Valeria Infante-Villagrán ${ }^{2}$, Celia Galve-González ${ }^{3}$ (D), Gabriela Flores-Oyarzo ${ }^{4}$ \\ and José Berríos-Riquelme ${ }^{5}$
}

check for updates

Citation: Maluenda-Albornoz, J.; Infante-Villagrán, V.; Galve-González, C.; Flores-Oyarzo, G.; BerríosRiquelme, J. Early and Dynamic Socio-Academic Variables Related to Dropout Intention: A Predictive Model Made during the Pandemic. Sustainability 2022, 14, 831. https:// doi.org/10.3390/su14020831

Academic Editors: Roy Rillera Marzo Siyan Yi, Mostafa Dianatinasab, Edlaine Faria de Moura Villela, Praval Khanal and Yulan Lin

Received: 2 December 2021

Accepted: 3 January 2022

Published: 12 January 2022

Publisher's Note: MDPI stays neutral with regard to jurisdictional claims in published maps and institutional affiliations.

Copyright: (C) 2022 by the authors. Licensee MDPI, Basel, Switzerland. This article is an open access article distributed under the terms and conditions of the Creative Commons Attribution (CC BY) license (https:// creativecommons.org/licenses/by/ $4.0 /)$.
1 Facultad de Psicología, Universidad San Sebastián, Sede Concepción, Concepción 4080871, Chile

2 Programa de Doctorado en Psicología, Departamento de Psicología, Universidad de Concepción, Concepción 4070386, Chile; valeria.a.infante.v@gmail.com

3 Departamento de Psicología, Universidad de Oviedo, 33003 Oviedo, Spain; celiagalvegon@gmail.com

4 Investigadora Independiente, Concepción 4080871, Chile; gabflores@udec.cl

5 Departamento de Ciencias Sociales, Universidad de Tarapacá, Iquique 1113749, Chile; jberrios@uta.cl

* Correspondence: Jorge.maluenda@uss.cl

\begin{abstract}
Social and academic integration variables have been shown to be relevant for the understanding of university dropout. However, there is less evidence regarding the influence of these variables on dropout intention, as well as the predictive models that explain their relationships. Improvements in this topic become relevant considering that dropout intention stands as a useful measure to anticipate and intervene this phenomenon. The objective of the present study was to evaluate a predictive model for university dropout intention that considers the relationships between social and academic variables during the first university semester of 2020. The research was conducted using a cross-sectional associative-predictive design, with a convenience sampling $(n=711)$ due to the restrictions of the pandemic period. The results showed a good fit of the proposed hypothetical model that explained $38.7 \%$ of dropout intention. Both social support and perceived social isolation predicted the sense of belonging and, through it, engagement. Previous academic performance predicted early academic performance and, through it, engagement. The set of variables predicted the intention to quit through engagement. These results are a contribution both to the understanding of the phenomenon and to guide potential interventions in the early stages of the university experience.
\end{abstract}

Keywords: dropout intention; perceived social isolation; perceived social support; engagement; sense of belonging; higher education

\section{Introduction}

\subsection{University Dropout and Dropout Intention}

University dropout in Latin America and the Caribbean is a critical problem, with rates that can reach $54 \%$. In addition, approximately $22 \%$ of the population between 25 and 29 years old has abandoned their studies [1]. In this context, the first year of university is the greatest concern as it produces a higher dropout rate in higher education, making the educational process difficult at an early stage [2]. Chile is no exception, reaching dropout rates of $26.4 \%$ at the higher education level and $23.1 \%$ at the university level during the first year of studies [3]. The effects of dropout include an impact at the individual and family level, with repercussions on the life project and the family economy [4,5] at the institutional level with respect to quality and efficiency indicators. At the social level, dropout affects social and economic development due to the decline in human capital [6].

In recent years, there has been an important interest in studying the dropout intention of university students as it is a variable that can be measured early to anticipate complete 
dropout. Its measurement in early stages, for example, during the first year, would influence the decision of the students through strategies to support them. For example, these strategies would help promote better social and academic integration in university. In addition, some research has shown the importance of studying the perceptions of university students with respect to their dropout intention, as dropout intention can negatively impact well-being and academic performance [7].

It has been observed that the variables that influence the social and academic integration of students are linked to dropout [8-11], and may also influence dropout intention [12-15]. However, the research is still incipient, and there is room for improvement in the refinement of the differential importance of these variables, as well as the elaboration of a theoretically coherent model that allows the prediction of their occurrence.

It is important to indicate that the COVID-19 pandemic has brought a series of important consequences for the development of university education. The COVID-19 pandemic gave rise to a remote or hybrid educational process, without the teachers and university systems having been sufficiently prepared to face this rearrangement [16-18]. This has implied an accelerated adjustment of teachers in the necessary tools for remote education, a change in teaching strategies, and the updating of technological supports $[19,20]$.

Mooney and Becker [21] conducted a study where they proposed that the events surrounding COVID-19 were a challenge for the sense of belonging of many students, mainly for those entering the first year. In total, $50 \%$ of the students who participated in the study reported that levels of stress and anxiety related to COVID-19 were extremely challenging or very challenging. This study showed that, to a greater extent, COVID-19 affects the sense of belonging in men and women who do not feel they belong, with the results being statistically significant in men. This could be explained by the fact that virtual environments are not able to replicate the key facets of presence [22]. An additional explanation is that the sense of belonging and the physical space of the campus are closely related [23], and that belonging increases with social interaction [24].

The characteristics of remote education in times of pandemic could introduce differences in the influence that predictive variables have on dropout intention in the context of a regular study. For example, students have had to adjust to the new educational conditions with difficulties related to access and technological literacy, the adjustment of the home to office space, and study and work conditions in very diverse socioeconomic backgrounds (or contexts) among families [25].

In addition to the abovementioned factors, today's educational process takes place in a different context than the usual process. Today, the educational process is marked by a lack of direct interpersonal contact, a lower possibility of teacher control over the student's activity, and, therefore, the need for skills among students to be able to face their learning more autonomously.

\subsection{Support and Perceived Social Isolation}

There are different sources of support that can be provided by the community, social networks, and trusted people. However, social support tends to come more frequently from trusted people with whom one shares a greater degree of intimacy [26].

Research has shown that peer and teacher support influence the decision to drop out of university studies $[15,27]$. This relationship arises as the most immediate support that students have during their studies is that of their significant teachers and peers.

Perceived social support is defined as the evaluation made by the student regarding the quantity and quality of social support available, if its use is necessary [28]. In this way, it constitutes a subjective perception of the availability of the social network and the satisfaction of personal needs through support [29].

Supports can fulfill both an expressive function with an end in itself (e.g., sharing a problem or a moment of pleasure) and an instrumental function aimed at achieving a specific objective or good (e.g., receiving education or information) [30]. This distinction is relevant if we consider the results observed in university dropout studies, where social 
interaction specifically linked to support in academic work showed a more important effect [31].

In the current educational context, social variables can play a very important role due to the confinement and forced social isolation of university studies. It is possible that isolation has effects in different dimensions, such as socio-emotional balance, which will be increased in students with pre-existing problems [32].

Perceived social isolation is defined as the subjective evaluation regarding the availability of contacts or social ties [33] to the extent necessary for each person.

The attributional discrepancy theory is important both for understanding perceived social support and social isolation. The subjective evaluation that the students make of their social relationships varies according to their own standards [34]. In this way, the perception of support and social isolation considers the level of social contact that people require. The perception of support and social isolation can each be heterogeneous. In other words, students may perceive more or less support, isolation, or social belonging with respect to the available objective levels $[28,33]$.

Both support and social isolation have shown their importance in university studies due to their impact on social integration of students and the consequences of this on mental health and the networks available to advance in academic activities [35,36], in addition to being directly related to lower dropout rates [37]. Therefore, the greater the social integration, the lower the probability of drop out, where social integration is being affected by both social support and social isolation.

College students who do not make effective connections with their peers and professors are likely to feel alienated and/or marginalized. When this situation is sustained over time, it can become an incentive for dropout [35]. In addition, it has been observed that social isolation can severely deteriorate the educational experience, being linked to anxiety, depression, and stress [35] and disengagement with studies [38]. However, having social support can act as a buffer for student stress and discomfort in difficult situations, favoring conditions that allow a better approach and decision making [39], which can act as a protective factor against dropout intention.

It has been observed that the perceived social support and the interpersonal relationships that students establish with their peers, teachers, and members of the university campus are fundamental aspects to develop a sense of belonging [40-44], an aspect inversely related to the dropout intention. This is as social support and positive interactions are essential for the development of a sense of belonging in university students [40,45]. The support of peers and parents has also shown to influence the sense of belonging to the institution and has been linked to a greater institutional engagement [46].

Student's social integration with peers and teachers has shown to be a direct and strong predictor of academic engagement and an indirect predictor of the intention to stay or drop out [47]. The perception of support from teachers has been negatively related to the dropout intention [48]. Therefore, the greater the social integration, the greater the academic engagement and the lower the dropout intention.

A few studies have directly measured social isolation in college students during the pandemic [49]. Regarding this specific scenario, it has been observed that social isolation influences the mental health of students [50-57].

Some studies during the current pandemic have observed similar results to those in the regular educational context: social isolation in university students is related to mental health effects such as stress, anxiety, and insomnia [58,59].

Social integration variables have been one of the most studied in recent years, among which, recently, social adaptation and the sense of belonging have become relevant $[27,60]$.

\subsection{Sense of Belonging}

The sense of belonging is defined as the perception of membership or feeling part of the educational organization (study program) in which a person studies [61]. Feelings of belonging to the career implies that the student feels valuable and respected in their own 
educational program [40,43-45,62-66]. It implies a perceived bond between the student and others, which unites them to a group or community, even in difficult moments or in the face of challenges [67], and the impulse that mobilizes them to create and maintain meaningful and lasting interpersonal relationships [68].

The model proposed in this study focuses on the sense of belonging to the study program in which the students study, so the kind of sense of belonging that is referred to in this study is the sense of career belonging.

The sense of belonging arises due to the process of integration of a person in their organization and, consequently, due to the levels of support or isolation perceived by the students. When students connect with the formal academic, social, and cultural learning environment of the academic community, they develop a sense of belonging that translates into a desire to stay and complete their educational goals [69].

Belonging students share cultural aspects of the organization and voluntarily participate in the life and activities of the organization [70]. When there is a deep sense of belonging, the student's self-definition can be connected to what defines the organization, affecting their identity and behavior [71].

The social integration of students fosters a sense of belonging to the community, a variable that has been shown to be a predictor of permanence in university studies in a regular educational context [46]. Therefore, when the student is socially integrated, it favors the development of a sense of belonging.

On the other hand, when students do not feel valued and respected by others, or do not feel that they belong to a social environment, they are more likely to drop out of their studies [72], the sense of belonging to the career being a significant predictor of the dropout intention in university students [73].

The link between the sense of belonging and the dropout intention is due in part to the fact that it strengthens the engagement of students. It has been observed that the similarity and connection that students perceive with respect to their immediate academic community has been a predictor of engagement [74]. It has also been shown to be a predictor of the exertion of committed behaviors such as respecting the rules or assuming more functions than the mandatory ones [75].

The pandemic of COVID-19, poses various challenges for university students, including adjusting to an online educational system while keeping their academic and work duties and responsibilities up to date, adjusting to changes in terms and schedules, and the lack of a space or physical context for interaction where they can share their concerns and experiences with peers [76]. In a study carried out by Markel and Guo [22] during the first months of the COVID-19 pandemic, they showed that, in virtual learning environments, although remote technologies can contribute to inclusion, they also pose additional barriers for students.

It has been observed that high levels in the sense of belonging in university students contribute to increasing their levels of participation, being able to seek help in the face of difficulties, feeling less alone, anxious, or depressed, increasing the use of self-regulation strategies, and raising levels of academic self-confidence and motivation [64,66,77]. In addition, various investigations have observed that the sense of belonging turns out to be a direct predictor of study engagement, dropout, and permanence in studies $[40,41,45,65,66,73,77-80]$.

\subsection{Academic Variables and University Dropout Intention}

The relationship between academic performance and dropout has been reported many times, showing, in general, that performance is a significant predictor of college dropout $[2,9]$.

Academic performance is understood as the level of knowledge demonstrated in an area or subject compared to the age norm and academic level [81]. However, in practical terms, performance is usually measured from classroom assessments that do not necessarily entail associated standardizations. Performance is commonly considered as the level of achievement that a student obtains in their training process, expressed through a numerical 
assessment [82]. Their relationship has been investigated and described as an academic precedent for dropping out of studies where the score in the University Selection Test (PSU) has been the most used in the Chilean context $[83,84]$.

The theoretical relationship between previous performance and dropout lies in the fact that previous performance reflects the academic abilities that students develop before entering higher education, which influence the academic integration process [85]. In this way, the level of prior academic preparation of students would influence the mastery of basic knowledge and skills necessary for current studies.

The relationship between academic performance during studies and dropout has been less explored and could be important in the student's decision making regarding whether to remain or abandon ongoing studies.

For Bernardo et al. [86] academic performance during studies operates as an indicator for the student about their degree of academic integration, which becomes a key element in the decision to remain or abandon studies. In addition, there is research that has shown its influence on student decision making about permanence and the effect it has on university dropout [87].

Early academic performance would operate as feedback on the effectiveness of the efforts made to study and the ability to face a university career. In addition, it becomes vital information to decide in terms of cost-benefit on the continuation of the studies [88].

\subsection{Engagement and Dropout Intention}

Different studies with university students have shown that the level of engagement exhibited by students proves to be a strong significant predictor of dropout in university students [13,73,89].

Engagement is understood as the set of manifestations of motivation with studies [90] which have developed, over the last decades, theories that group this phenomenon into three main dimensions [91]: the behavioral dimension, which would refer to all those behaviors carried out by the student who is interested in learning; the cognitive dimension, which would refer to all those thoughts, beliefs, and perceptions about the importance of academic work and the effort that it entails; and the emotional dimension, which includes the feelings and attitudes that the student experiences around the institution.

In this sense, the engagement proposal is based on the Self-determination Theory (SDT) [92]. This is understood as the set of manifestations of motivation for studies [90] that arises from the satisfaction of the needs of competence, autonomy, and relationship in the context of studies [90]. In the educational context, the need for autonomy is satisfied when the student feels that he or she makes choices and is motivated by intrinsic rather than external factors. The need for competence is favored when the structure of the class allows the desired results to be achieved. The need to be related is satisfied when the student establishes relationships with their teachers and peers based on support and concern [90].

As for the relationship between engagement and dropout intention, there is a much smaller volume of research. Despite this, it has been observed that engagement is also a strong significant predictor of dropout intention [93,94].

During 2020 and 2021, most of the published studies have shown that the current educational context has generated damage in the motivation and participation of students [20,95] and a decrease in their levels of engagement [96,97]. Some studies have attributed this deficit to factors associated with mental health such as stress, anxiety, and insomnia during confinement, which affect the energy and vigor levels associated with student engagement associated with the situation of social isolation and remote education [58,59].

A predictive associative study during the pandemic with university students from nine countries found that engagement was a positive predictor of performance and a negative predictor of dropout intention [98]. Another study carried out during the pandemic with Chilean university students observed that the expectations about their level of engagement 
and about their performance during the semester were shown to be predictors of their early dropout intention [19].

All the variables previously described are considered dynamic variables, as they can change through intervention and constitute a set of key factors to understand the phenomenon of university dropout, as the evidence presented preliminarily has shown. The variables included in this research represent two specific virtues: (a) are variables that can be influenced during university studies favoring potential interventions; (b) are variables that can be measured in very early stages of the educational process, therefore favoring a rapid response by universities in the face of risk situations.

The main objective of the present research was to evaluate a predictive model for the university dropout intention that considers the relationships between previous and early academic performance, sense of belonging to the career, support, and perceived social isolation in the career, and academic engagement during the first university semester of 2020. This study, therefore, has been developed during the start of the COVID-19 pandemic in Chile. The hypothetical model of relationships based on the theoretical and empirical aspects previously raised is observed in Figure 1.

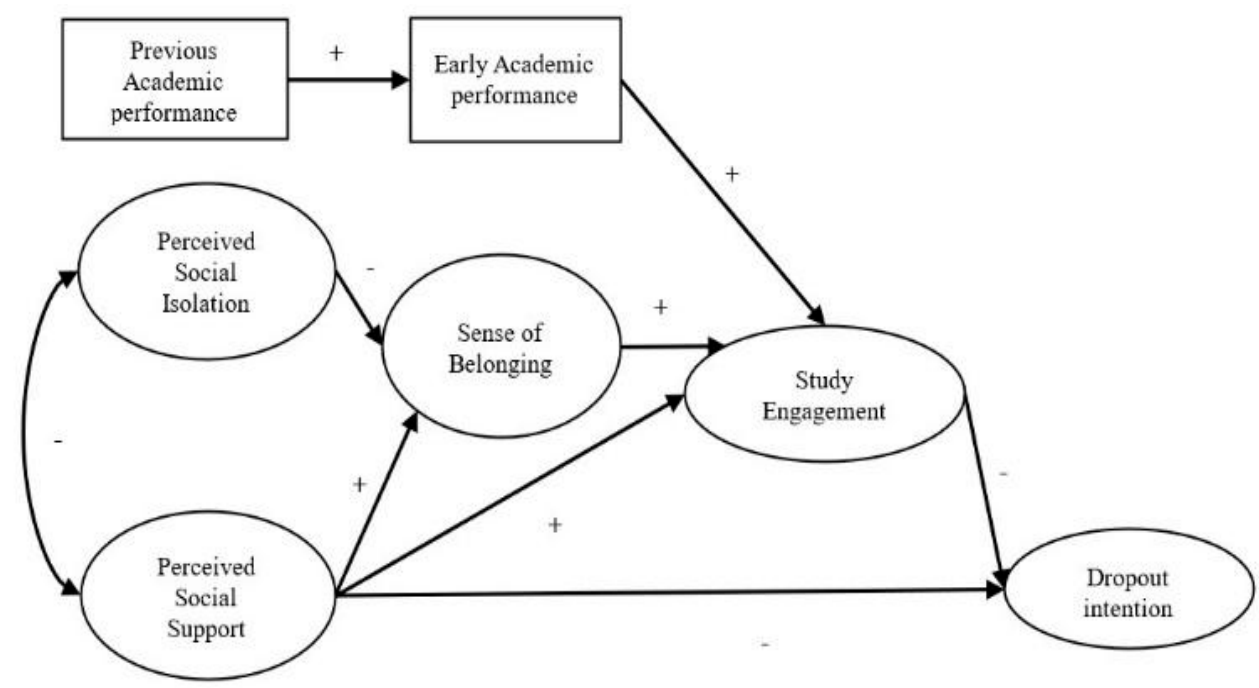

Figure 1. Hypothetical model for Dropout Intention.

\section{Materials and Methods}

\subsection{Participants}

The sample was made up of 711 first-semester students enrolled in 2020 from a Chilean university, equivalent to $16.78 \%$ of the total population. It was distributed among 285 men $(40.09 \%), 422$ women $(59.35 \%)$, and 4 students who identified with another preference $(0.56 \%)$. The average age of the students was 18.8 years, with a standard deviation of 1.7 years, a minimum of 17 years and a maximum of 33 .

The students were recruited through the authorities of their respective careers; their participation was voluntary and did not imply compensation of any kind.

The distribution of students according to the disciplinary area of their career and the dropout percentage reported by the degree in which the student enrolled during 2020 is shown in Table 1.

\subsection{Design}

The current research was carried out using a cross-sectional associative-predictive design. The selection of the participants was carried out using a non-probability convenience sampling due to the restrictions imposed by the COVID-19 pandemic for access to the participants. All first-semester students enrolled in 2020, belonging to a Chilean university, were invited to participate openly and voluntarily. The voluntary invitation was made by 
email. The students read and accepted an informed consent approved by the university's research ethics committee, which led them to the instrument in electronic format. The data collection was carried out during May and June of the year 2020 to have students who have had initial experience at the university and have their first qualifications.

Table 1. Distribution of participants by career area and dropout rate.

\begin{tabular}{ccccc}
\hline Career Area & $\begin{array}{c}\text { High Dropout } \\
\text { Rate } \\
\mathbf{( N )}\end{array}$ & $\begin{array}{c}\text { Medium } \\
\text { Dropout Rate } \\
\mathbf{( N )}\end{array}$ & $\begin{array}{c}\text { Low Dropout } \\
\text { Rate } \\
\text { (N) }\end{array}$ & $\begin{array}{c}\text { Total } \\
(\mathbf{N})\end{array}$ \\
\hline $\begin{array}{c}\text { Legal, economic, and } \\
\text { administrative }\end{array}$ & 20 & 28 & 5 & 53 \\
$\begin{array}{c}\text { Agriculture and forestry } \\
\text { technology and sciences } \\
\text { Social sciences and } \\
\text { humanities }\end{array}$ & 21 & 17 & 48 & 86 \\
$\begin{array}{c}\text { Exact and natural sciences } \\
\text { Technology and health } \\
\text { sciences }\end{array}$ & 64 & 57 & 46 & 167 \\
$\begin{array}{c}\text { Engineering science and } \\
\text { technology }\end{array}$ & 22 & 11 & 39 & 120 \\
\hline Total & 48 & 42 & 91 & 155 \\
\hline
\end{tabular}

\subsection{Instruments}

An electronic questionnaire was made from different instruments that have been adapted to the Chilean context with recent evidence of validity and reliability for the variables of this research. In those studies, all the psychometric properties were tested using Confirmatory Factor Analysis (CFA), the Cronbach's alpha index, and the McDonald's omega index.

The instrument consisted of 33 items whose response format was through a Likerttype scale of 1 to 7 points ( 1 indicates maximum disagreement and 7 indicates maximum agreement). It included:

- $\quad$ University Student Engagement Scale (15 items) created by Maroco et al. [89] and adapted to Chilean university students [13]. This instrument measures engagement as the result of high motivation for studies in the career context. The validation study showed a bifactorial structure with one general factor and three subfactors: Interest (5 items), Effort (5 items), and Participation (5 items). In the adapted version the fit indices showed good performance of the bifactorial model $\left(\chi^{2}=210.276, p<0.001\right.$; RMSEA $=0.047$ (95\% IC: 0.040-0.055; CFI $=0.967 ;$ TLI $=0.954)$ as well as reliability $(\alpha=0.841 ; \omega=0.843)$ and criterion validity.

- Membership factor of the Organizational Identification Questionnaire with Study Centers created by Yáñez et al. [99] and adapted to Chilean university students [100]. It measures, through 4 items, the degree of belonging perceived by the students within the career they are studying. The adapted version showed good fit indices for a one factor structure $\left(\chi^{2}=3.126, p=0.20\right.$; RMSEA $=0.028$ (95\% IC: $0.000-0.085 ;$ CFI = 0.999; TLI $=0.999 ;$ RSMR $=0.005)$ as well as reliability $(\alpha=0.815 ; \omega=0.834)$.

- $\quad$ Perceived social support items inspired by the measurement carried out in Chilean university students in the FONDECYT project $N^{\circ} 1161502$, adapted to refer specifically to the career level [101]. These 4 items measure the perception of having a reliable network in the university context (by peers and professors) when it is needed. It showed good fit indices for a one factor structure $\left(\chi^{2}=11.616, p=0.003\right.$; RMSEA $=0.072$ (95\% IC: 0.041-0.131; CFI $=0.997 ; \mathrm{TLI}=0.992 ; \mathrm{RSMR}=0.011)$ as well as reliability $(\alpha=0.798 \omega=0.823)$.

- Perceived social isolation items based on the UCLA Loneliness Scale-revised version [102] adapted to refer specifically to the career level. It measures through 4 items 
the perception of lack of social relationships and meaningful ties in the university context (with peers and professors). It showed good fit indices for a one factor structure $\left(\chi^{2}=5.741, p=0.056 ;\right.$ RMSEA = 0.051 (95\% IC: 0.000-0.103; CFI = 0.999; TLI = 0.997; RSMR $=0.008)$ as well as reliability $(\alpha=0.800 \omega=0.817)$.

- $\quad$ The dropout intentions were measured from 4 items taken from FONDECYT project $\mathrm{N}^{\circ} 1161502$ that have been previously used in the same population and that refer to the student's dropout intention of university [101]. It showed good fit indices for a one factor structure $\left(\chi^{2}=9.732, p=0.007\right.$; RMSEA $=0.074$ (95\% IC: $0.032-0.123$; $\mathrm{CFI}=0.999 ; \mathrm{TLI}=0.996 ; \mathrm{RSMR}=0.004)$ as well as reliability $(\alpha=0.834 \omega=0.834)$.

- $\quad$ One item was considered to collect the prior academic performance, which is measured through the simple average of grades obtained by the students in the national university selection test called "Prueba de Selección Universitaria" (PSU).

- $\quad$ Finally, one item was considered to collect early academic performance. It corresponds to the simple average of grades obtained by the student in the middle of the first academic semester (May-June 2020).

\subsection{Analysis}

The evaluation of the proposed model and the associated research hypotheses followed the 3 phases proposed by Kline [103] for the evaluation of structural models:

- $\quad$ Specification of the evaluated model. The included variables and its relationships were specified based on the literature review. The result was the hypothetical model presented in Figure 1 which consisted of 5 latent and 2 observed variables as principal components of this research.

- $\quad$ Estimation by "Weighted Least Square Mean and Variance" (WLSMV). It allows work with continuous and categorical variables at the same time [104]. In addition, it is an estimator that works well with samples of moderate size and complex models [105].

- $\quad$ Evaluation of the model. Goodness of fit was calculated to evaluate the hypothetical model. Based on these results and theoretical background decisions about re-specified model were made. The reference values used to evaluate goodness of fit were: significant $\chi^{2}$, decrease in the NCP value in the re-specified model, CFI and TLI $\geq 0.90$, RMSEA $\leq 0.08$ [106], and $\omega>0.70, \alpha>0.70$ [106,107]. All analyses were performed using the statistical software MPLUS version 8.

Mediation analysis to study sense of belonging and study engagement as possible intervention variables were made using MPLUS version 8.

\section{Results}

\subsection{Preliminary Analyses}

Table 2 shows the means, standard deviations, skewness, kurtosis, minimum, and maximum value. All asymmetry and kurtosis values were less than 3 , which show that the structure of the data tends to approximate a univariate normal distribution except for the dropout intention, which presents a kurtosis value slightly higher than this criterion. The results of the Kolmogorov-Smirnov normality test did not show statistically significant differences in any of the variables evaluated. This result corroborates what was previously found in the descriptive analysis presented. Thus, the data are assumed to have a univariate normal distribution.

\subsection{Research Results}

The evaluation of the proposed model showed an appropriate fit in all the fit indices tested except for the $\chi^{2}$ index, which turned out to be significant. However, it has been observed that this indicator tends to be misaligned with large sizes [105]. Its correction through the NCP ratio reaches a small value, an indicator of a good fit [106]. All these values are shown in Table 3. It is important to add that the two criteria to obtain the minimum required/desirable sample size proposed by Hair et al. [106] were considered: the 10x rule 
and the minimum r2. According to the above, it was observed that the recommended, as well as the desirable, minimum sample size was 308 .

Table 2. Descriptive statistics.

\begin{tabular}{cccccccc}
\hline Variable & $\mathbf{n}$ & Min & Max & Mean & SD & Skewness & Kurtosis \\
\hline Previous academic performance & 711 & 200 & 809 & 623.56 & 71.12 & -0.42 & 2.25 \\
Early academic performance & 711 & 30 & 70 & 57.43 & 6.85 & -0.70 & 0.26 \\
Sense of belonging & 711 & 4 & 28 & 19.99 & 5.04 & -0.60 & -0.19 \\
Perceived social support & 711 & 4 & 28 & 17.29 & 5.59 & -0.32 & -0.50 \\
Isolation & 711 & 4 & 28 & 11.73 & 5.39 & -0.54 & -0.46 \\
Study engagement & 711 & 18 & 105 & 82.48 & 11.93 & -0.94 & 1.99 \\
Dropout intentions & 711 & 4 & 28 & 7.19 & 4.40 & 1.77 & 3.30 \\
\hline
\end{tabular}

Table 3. Initial model Fit Indices.

\begin{tabular}{cccccccc}
\hline Model & $\chi^{2}$ & gl & NCP & CFI & TLI & RMSEA & SRMR \\
\hline Initial model & $\begin{array}{c}2102.512 ; p< \\
0.001\end{array}$ & 485 & 2.27 & 0.931 & 0.924 & $\begin{array}{c}0.068 \text { IC 95\% } \\
(0.065-0.072)\end{array}$ & 0.071 \\
\hline
\end{tabular}

The standardized beta values of the model show significant values in most of the relationships proposed between the variables, except for the routes that include the direct influence of perceived social support on study engagement $(\beta=0.024, p>0.05)$ and on dropout intention $(\beta=-0.030, p>0.05)$. For the other relationships, the observed standardized beta values were significant and fluctuated between moderate and strong values $(\beta=0.217 \beta=-0.796, p<0.01)$. The initial model is shown in Figure 2 .

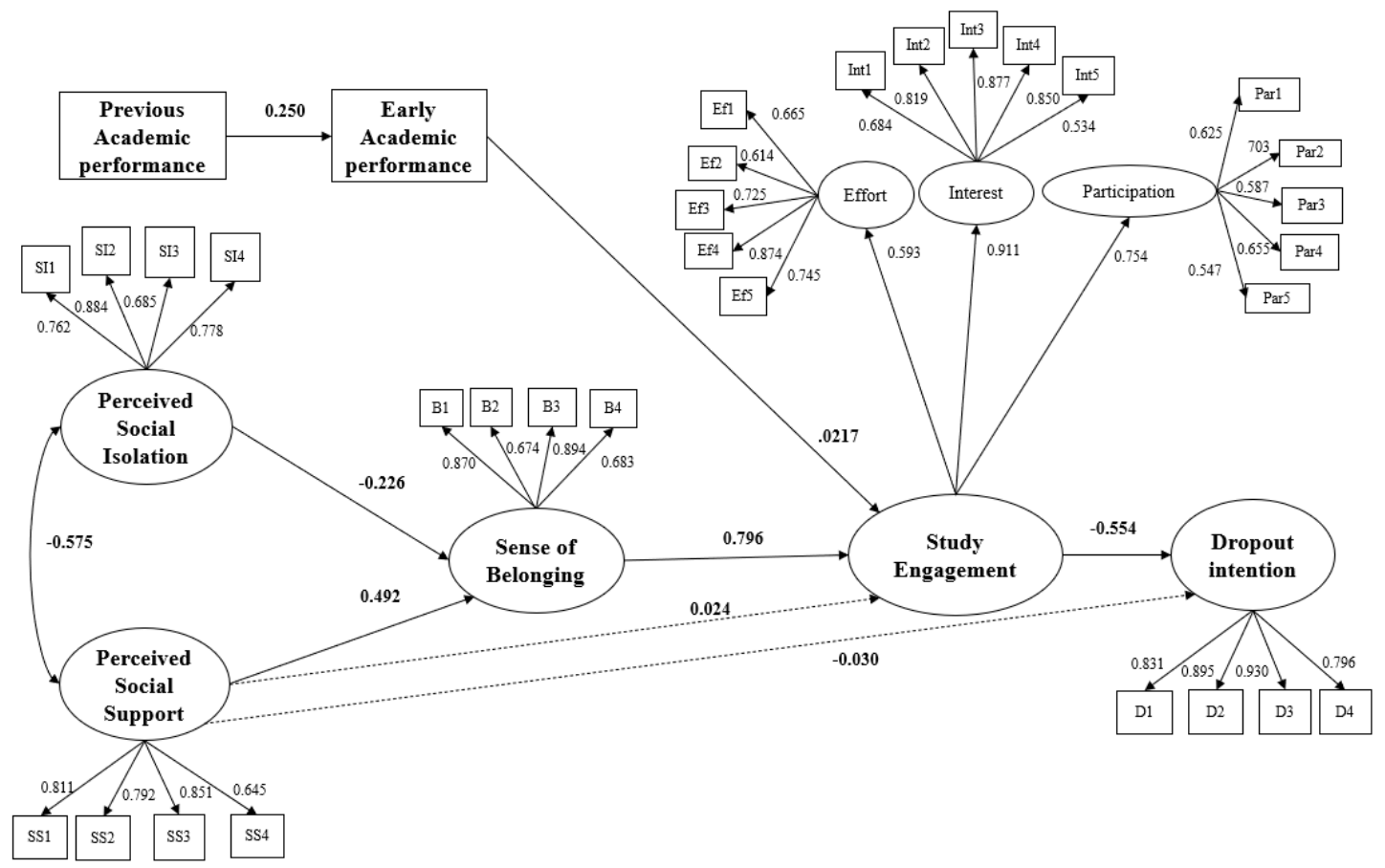

Figure 2. Tested model for Dropout Intention. $p$ values were all $p<0.001$.

A re-specified model was evaluated only with significant relations, considering as a hypothesis that the effect of social support on the dropout intention occurs through a double mediation given by the sense of belonging and academic engagement. The new model improved all the fit indices (Table 4) except for $\chi^{2}$, which turned out to be significant. However, the contrast in the NCP values showed a better fit in the second model. The 
re-specified model and its values are shown in Figure 3 and Table 4, respectively. In this sense, the new model showed a better fit in all the indicators and reflected $38.7 \%$ of the explanation for dropout intention.

Table 4. Re-specified model Fit Indices.

\begin{tabular}{cccccccc}
\hline Model & $\boldsymbol{x}^{2}$ & gl & NCP & CFI & TLI & RMSEA & SRMR \\
\hline $\begin{array}{c}\text { Re-specified } \\
\text { model }\end{array}$ & $\begin{array}{c}1995.754 ; p< \\
0.001\end{array}$ & 486 & 2.12 & 0.955 & 0.950 & 0.066 IC 95\% \\
$(0.063-0.069)$ & 0.071 \\
\hline
\end{tabular}

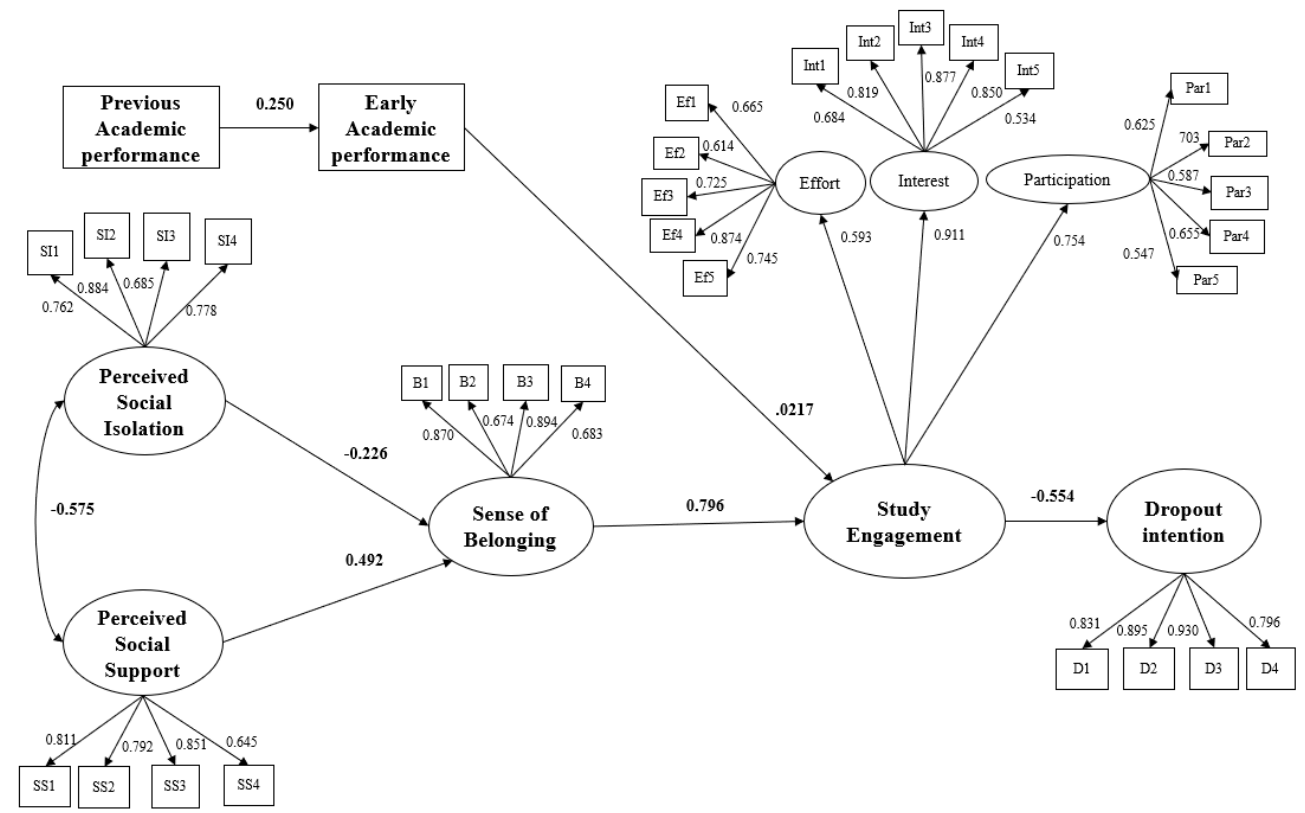

Figure 3. Re-specified model for Dropout Intention. $p$ value were all $p<0.001$.

\subsection{Mediation Analysis}

The evaluation of mediation analysis considering study engagement as a dependent variable showed an indirect effect of perceived social isolation on study engagement through the sense of belonging (Table 5). A direct effect of perceived social support on study engagement was found, but not a direct effect of perceived social isolation on study engagement. Additionally, an indirect effect of both variables mediated by sense of belonging on study engagement was found.

Table 5. Standardized estimates of indirect, direct, and total effects of perceived social isolation and perceived social support on study engagement with sense of belonging as a mediator.

\begin{tabular}{lcc}
\hline \multicolumn{1}{c}{ Effect [95\% IC] } & Estimate & $p$ Value \\
\hline $\begin{array}{l}\text { Direct effects } \\
\text { Perceived social isolation } \rightarrow \text { Study Engagement }\end{array}$ & -0.009 & 0.905 \\
$\begin{array}{l}\text { Perceived social support } \rightarrow \text { Study Engagement } \\
\text { Indirect effects }\end{array}$ & 0.259 & $<0.001$ \\
$\begin{array}{l}\text { Perceived social isolation } \rightarrow \text { Sense of belonging } \rightarrow \text { Study } \\
\text { Engagement }\end{array}$ & -0.197 & $<0.001$ \\
$\begin{array}{l}\text { Perceived social support } \rightarrow \text { Sense of belonging } \rightarrow \text { Study } \\
\text { Engagement }\end{array}$ & 0.161 & $<0.001$ \\
Total & & \\
$\begin{array}{l}\text { Perceived social isolation } \rightarrow \text { Study Engagement } \\
\text { Perceived social support } \rightarrow \text { Study Engagement }\end{array}$ & -0.206 & 0.007 \\
\hline
\end{tabular}


The evaluation of mediation analysis considering dropout intention as a dependent variable showed an indirect effect of sense of belonging on dropout intention through the study engagement but not a direct effect on it (Table 6).

Table 6. Standardized estimates of indirect, direct, and total effects of sense of belonging on dropout intention with study engagement as a mediator.

\begin{tabular}{lcc}
\hline \multicolumn{1}{c}{ Effect [95\% IC] } & Estimate & $p$ Value \\
\hline $\begin{array}{l}\text { Direct effects } \\
\text { Sense of belonging } \rightarrow \text { Dropout intention }\end{array}$ & -0.006 & 0.756 \\
$\begin{array}{l}\text { Indirect effects } \\
\text { Sense of belonging } \rightarrow \text { Study engagement } \rightarrow \text { Dropout intention }\end{array}$ & -0.256 & $<0.001$ \\
$\begin{array}{l}\text { Total } \\
\text { Sense of belonging } \rightarrow \text { Dropout intention }\end{array}$ & -0.306 & $<0.001$ \\
\hline
\end{tabular}

\section{Discussion}

\subsection{General Model: University Dropout Intention}

The present research proposed a model based on social and academic integration variables to explain university dropout intention in first-year students. The research is based on two essential assumptions that are at the base of the hypothetical model proposed. Firstly, it was argued that the integration of a student in the social life of a career is related to the sense of belonging, a variable with a strong influence on the degree of engagement that he or she manifests with their academic activities and with the human group that makes up the career, which influences the decision to stay or drop out of their current university. Secondly, it has been proposed that academic performance can act through the capacities developed to face academic life and as a source of information that affects decision making regarding staying or leaving studies.

To these assumptions, three key specifications are added, which this research aims to provide evidence for. Firstly, the importance of specifying the measurement of variables at the career level, as it is the immediate context in which students operate and the one that may have the greatest impact on their decisions during the educational process. The only exception to this condition was previous performance due to its past nature. Secondly, the importance of considering variables that can be measured early in the educational process was raised. This is due to the need to have relevant information regarding the decision to dropout or remain in the studies which is possible to know quickly and which allows decisions to be made before the dropout has been done. Thirdly, the need to work mainly with predictive variables that were potentially modifiable (dynamic variables) was proposed to contribute to the knowledge that can be applied in the improvement of institutional processes.

From these results, it is possible to indicate the fulfillment of the objective of this study. The results showed an adequate general model fit, with most of the hypothetical relationships raised being significant with moderate to strong values. However, the routes that include the direct influence of perceived social support on study engagement and on dropout intention were not statistically significant, the reason it was decided to re-specify the model. The new model showed a better fit in all the indicators and reflected $38.7 \%$ of the explanation for dropout intention.

From the re-specified model, it is possible to conclude that both the social [48] and academic variables considered have a relevant influence on the dropout intention, reaffirming what has already been described in the preliminary research $[73,98]$.

In the present model, the influence of the social and academic integration variables predicts engagement, which acts as the main mediating variable of the model. The influence of social support and perceived social isolation, in turn, is mediated by the sense of belonging to the career, a variable that exerts a strong influence on engagement. The influence of previous academic performance on engagement is in turn predicted by early academic performance. 
The original model was proposed with an independent influence between social and academic variables due to its measurement in the same time cut-off. It is not reasonable to argue that current perceived social support, isolation, and sense of belonging influenced early performance that had already been achieved. The relationship of the variables taken into account in the model will be presented, classifying them according to whether they are of a social or academic nature.

\subsection{Social Variables and the Dropout Intention}

The observed results suggest that the perceived social integration, given by the perception of support and lack of isolation, affects the sense of belonging they perceive to the human group that makes up their career. The sense of belonging, in turn, affects the engagement experienced by students, mobilizing specific motivational components such as interest, participation and effort linked to studies. Experienced engagement is strongly linked to early dropout intention. This chain of relationships shows the relevance of social variables on the motivation of students and, through it, on their decisions associated with the continuity of their studies, especially if the emotional dimension is considered, as previously stated.

It is important to indicate that the measures carried out contemplate perceptions about social integration, which highlight the importance of its evaluation in the measure of individual needs, according to the approaches of the theory of attributional discrepancy [34].

It is relevant to remember that, in this study, social variables have been measured considering focus on relationships with peers and teachers, showing the relationship between these and dropout intention, according to previous research with Chilean students $[13,19,29]$. The results suggest the importance of these relationships within the study program community, highlighting their important influence on dropout intention. This could help clarify the types of support and isolation relevant to dropout intention.

Social support did not show to be a predictor of engagement, in the final model, as suggested in the initial model. As mentioned, the results show that the influence of social variables is explained by the presence of a sense of belonging. In this way, it is possible to observe that the social support of peers and teachers can affect the engagement of students by affecting how much they feel they belong to their career. Although mediation analysis showed a direct influence of perceived social support on study engagement, this influence is explained for the mediator role of sense of belonging. This may be indicating that strengthening sense of belonging is key to improve study engagement. At the same time, it is important to highlight that the sense of belonging has a negative relationship with dropout intention, explained by study engagement. Thus, it is important to work with students' social support and relationships in order to improve sense of belonging and study engagement. This can be a way to reduce university dropouts.

However, it seems important to understand that engagement is understood as the set of manifestations of motivation by studies [90] that include behavioral, cognitive and emotional dimensions [91]. This means that taking these dimensions into account is essential to understand the correlation between academic variables and the intention to remain in higher education.

At this point the theory of attributional discrepancy becomes relevant again, as how much support and how much belonging the students perceive and need is an idiosyncratic aspect of their experience. This finding is an important contribution given that most of the previous research establishes direct relationships between support and engagement $[74,108,109]$.

Social support was also not shown to be a direct predictor of dropout intention. As in the previous case, the observed mediations show that social variables influence belonging and, through this, engagement. This last variable once again plays a key role as the set of social variables only affects dropout intention by affecting the motivation of students. This finding also contributes to a deeper understanding considering that preliminary research focused on the direct relationship of social support and the dropout intention. 
In the same way, the perceived social integration could have been modified taking into account the COVID-19 pandemic. This perceived social integration, as well as the sense of belonging to the institution, may have been diminished to the detriment of faceto-face classes, a fact that will need to be taken into consideration for future research. In addition, social isolation and the sense of loneliness have also been variables that have suffered for variations due to this situation, as has been observed in studies such as that of Zurlo et al. [110].

\subsection{Academic Variables and Dropout Intention}

The results reaffirm what has already been observed in previous research. On the one hand, previous academic performance is a predictor of early academic performance [111]. However, the form of influence of previous academic performance on early one is something that should be deepened in later research, as it is possible that it is indicative of the influence of previous learning and/or the previously developed sense of self-efficacy on current learning.

Early academic performance is a predictor of engagement, as observed in previous research [112,113]. At this point, it is possible that early academic performance acts as an informative factor [86] that fuels student motivation for studies.

Neither of the two variables was shown to be a direct predictor of the dropout intention, according to the original approach, with engagement being an important mediator of its influence on the dropout intention. Thus, both types of performance only affect the dropout intention by affecting this cognitive-motivational variable.

It is also important to note that academic performance may not have shown to be a predictor of dropout intention due to the time the data was collected, as student grades tend to change as they adapt to the new educational context, not ruling out that this may influence later.

However, it is also important to understand that the current contingency due to the COVID-19 pandemic has been able to influence the results of the research, considering that early academic performance of students may have been modified considering the online modality. In addition, this may have influenced the engagement of students to a degree. Therefore, the interpretation of the results obtained must take into account the current contingency in order to be able to replicate the data in detail in the future and in different contexts.

\subsection{Applications of the Results}

On the one hand, the results contribute, in a certain way, to a better understanding of the relationships between the variables that have been analyzed throughout the investigation, deepening and distinguishing the relative influence of the variables. In this way, as has been discussed, new lines of research emerge and contribute to furthering the understanding of the phenomenon.

On the other hand, they contribute to the identification of relevant variables for the dropout intention and their relationships. As indicated, the variables included are susceptible to early detection (except for previous performance). This knowledge can contribute to the development of preventive actions that contribute to the social and academic integration of the student body, to maintain and increase their engagement and to reduce university dropout intention and therefore the consummate abandonment.

In order to prevent or alleviate the phenomenon of university dropout, some recommendations can be outlined, such as the implementation of actions that promote adaptation in the university environment with programs such as reception days [114] or programs to help the retention through the implementation of tutoring programs, first-year seminars, or the improvement of the use of technology to make teaching more flexible and motivating for students, among others [115]. These and other measures could improve social and academic adaptation of the student, which in turn will lead to greater support mechanisms for not dropping out during the first year (one of the academic years in which the risk 
of dropping out increases). In addition, the improvement of the use of new technologies since the beginning of higher education will allow accessibility and better understanding of the use of Information and Communication Technologies to all those who are studying in online or hybrid mode as a consequence of the COVID-19 pandemic.

\subsection{Limitations}

This research has some limitations. On the one hand, this sample, although it represents a significant amount of the population, is limited to a single educational institution, which limits the possibilities of extrapolating the results to different contexts. For this reason, the results contribute to suggest the indicated relationships and the proposed explanations so that they are deepened in later research. However, in future research, we will consider deepening the analysis, incorporating a complete mediation model to analyze the mediations produced between the academic and social variables of the model, engagement, and the intention to drop out.

On the other hand, this model does not consider other variables that could be important, such as self-efficacy perceived by the students. This variable could properly explain the relationship between performance and engagement. According to De Besa et al. [116], the more perceived self-efficacy increases, that is, the more aware the individual is that they have their own abilities to carry out any action, the more their expectations of results increase. Therefore, future research should take these limitations into account to be able to propose a more adjusted model according to the results obtained in the present research. We also consider it relevant to retest the model in normal contexts, without COVID-19.

Considering that the instruments used are self-report, this can generate simulation biases such as social desirability in the responses or scalar errors. In addition, there are limitations inherent to the research design as, as it is transversal, a sample is taken from a specific moment, not allowing causal relationships to be established.

Author Contributions: Conceptualization, J.M.-A., V.I.-V., C.G.-G., G.F.-O. and J.B.-R.; methodology, J.M.-A., V.I-V., C.G.-G., G.F.-O. and J.B.-R.; software, J.M.-A., V.I.-V., C.G.-G., G.F.-O. and J.B.-R.; validation, J.M.-A.; formal analysis, J.M.-A., V.I.-V., C.G.-G., G.F.-O. and J.B.-R.; investigation, J.M.-A., V.I.-V., C.G.-G., G.F.-O. and J.B.-R.; resources, J.M.-A., V.I.-V., C.G.-G., G.F.-O. and J.B.-R.; data curation, J.M.-A.; writing-original draft preparation, J.M.-A., V.I.-V., C.G.-G., G.F.-O. and J.B.-R.; writingreview and editing, J.M.-A., V.I.-V., C.G.-G., G.F.-O. and J.B.-R.; visualization, J.M.-A., V.I.-V., C.G.-G., G.F.-O. and J.B.-R.; supervision, J.M.-A.; project administration, J.M.-A.; and funding acquisition, J.M.-A. All authors have read and agreed to the published version of the manuscript.

Funding: This research was funded by the Agencia Nacional de Investigación y Desarrollo (ANID), Chile; through the scholarship for doctoral studies, grant number 21180225.

Institutional Review Board Statement: The study was conducted in accordance with the Declaration of Helsinki and approved by the Institutional Review Board (or Ethics Committee) of Universidad de Concepción, Chile (protocol code CEBB 645-2020 approved in April 2020). for studies involving humans.

Informed Consent Statement: Informed consent was obtained from all subjects involved in the study.

Data Availability Statement: Data base is available in: https:/ /bit.ly/3qILkrw.

Conflicts of Interest: The authors declare no conflict of interest.

\section{References}

1. Ferreyra, M.M.; Avitabile, C.; Botero, J.; Haimovich, F.; Urzúa, S. Momento Decisivo: La Educación Superior en América Latina y el Caribe; Grupo Banco Mundial: Washington, DC, USA, 2017. [CrossRef]

2. Ortiz-Lozano, J.M.; Rua-Vieites, A.; Bilbao-Calabuig, P.; Casadesús-Fa, M. University student retention: Best time and data to identify undergraduate students at risk of dropout. Innov. Educ. Teach. Int. 2018, 57, 74-85. [CrossRef]

3. Servicio de Información en Educación Superior. Informe 2020 Retención de 1er año de Pregrado Cohortes 2015-2019; Ministerio de Educación: Santiago, Chile, 2020.

4. Lattuada, M.J. Deserción y retención en las unidades académicas de Educación Superior: Una aproximación a las causas, instrumentos y estrategias que contribuyen a conocer y morigerar su impacto. Debate Univ. 2017, 10, 100-113. 
5. Herrero, E.T.; Galavís, I.A.; Contreras, A.U.; Diez, F.J.H.; Gutiérrez, A.B.B. Intención de abandonar la carrera: Influencia de variables personales y familiares. Rev. Fuentes 2020, 2, 142-152. [CrossRef]

6. Morentin-Encina, J.; Velázquez, B.B.; Mateus, S. ¿Igualdad de oportunidades? Más que el mero acceso: Trayectorias y narrativas de jóvenes en fracaso y abandono educativo en España y Portugal. Rev. Fuentes 2019, 21, 143-149. [CrossRef]

7. Bethencourt, J.T.; Cabrera, L.; Hernández-Cabrera, J.A.; Álvarez-Pérez, P.; González-Alfonso, M. Variables psicológicas y educativas en el abandono universitario. Rev. Electrónica Investig. Psicoeduc. 2008, 6, 603-622.

8. González-Ramírez, T.; Pedraza-Navarro, I. Variables sociofamiliares asociadas al abandono de los estudios universitarios. Educ. Siglo XXI 2017, 35, 365-388. [CrossRef]

9. Bernardo, A.; Cervero, A.; Esteban, M.; Tuero, E.; Casanova, J.R.; Almeida, L.S. Freshmen Program Withdrawal: Types and Recommendations. Front. Psychol. 2017, 8, 1544. [CrossRef] [PubMed]

10. Fernandez-Castañon, A.C.; Bernardo, A.; Esteban, M.; Tuero, E.; Carbajal, R.; Núñez, J.C. Influencia en el abandono universitario de variables relacionales y sociales. Rev. de Estud. e Investig. en Psicol. y Educ. 2017, 12, 46-49. [CrossRef]

11. Matteo, R.; Angeli dos Santos, A.; Portela, S. Motivos para evasão, vivências acadêmicas e adaptabilidade de carreira em universitários. Psico 2016, 47, 288-297. [CrossRef]

12. Castro-Lopez, A.; Cervero, A.; Galve-González, C.; Puente, J.; Bernardo, A.B. Evaluating critical success factors in the permanence in Higher Education using multi-criteria decision-making. High. Educ. Res. Dev. 2021, 1-19. [CrossRef]

13. Maluenda-Albornoz, J.; Varas-Contreras, M.; Díaz-Mujica, A.; Bernardo, A. Propiedades Psicométricas del University Student Engagement Inventory en Estudiantes de Ingeniería Chilenos. Rev. Iberoam. Diagn. Eval. Avaliação Psicol. 2020, 4, 77-90. [CrossRef]

14. González, A.F.; Tomás, E.A.; Gutiérrez, A.B.B.; Fernández-Castañón, A.C.; García, M.E.; Pizarro, P.S. Variables relacionadas con la intención de abandono universitario en el periodo de transición. Rev. D'innovació Docent Univ. 2018, 10, 122-130. [CrossRef]

15. Bernardo, A.; Esteban, M.; Fernández, E.; Cervero, A.; Tuero, E.; Solano, P. Comparison of Personal, Social and Academic Variables Related to University Drop-out and Persistence. Front. Psychol. 2016, 7, 1610. [CrossRef] [PubMed]

16. Coman, C.; Tiru, L.G.; Meseșan-Schmitz, L.; Stanciu, C.; Bularca, M.C. Online Teaching and Learning in Higher Education during the Coronavirus Pandemic: Students' Perspective. Sustainability 2020, 12, 10367. [CrossRef]

17. Potra, S.; Pugna, A.; Pop, M.D.; Negrea, R.; Dungan, L. Facing COVID-19 challenges: 1st-year students' experience with the romanian hybrid higher educational system. Int. J. Environ. Res. Public Health 2021, 18, 3058. [CrossRef]

18. Rosario-Rodríguez, A.; González-Rivera, J.A.; Cruz, A.; Rodríguez-Ríos, L. Demandas Tecnológicas, Académicas y Psicológicas en Estudiantes Universitarios durante la Pandemia por COVID-19. Rev. Caribeña Psicol. 2020, 4, 176-185. [CrossRef]

19. Maluenda-Albornoz, J.; Gutiérrez, A.B.; Galve-González, C.; Flores-Oyarzo, G.; Infante-Villagrán, V.; Díaz-Mujica, A. Variables predictoras de la expectativa de desempeño y la intención de abandono en contexto de educación virtual de emergencia en estudiantes universitarios chilenos. Rev. Caribeña Investig. Educ. 2021, 5, 81-91. [CrossRef]

20. Zaccoletti, S.; Camacho, A.; Correia, N.; Aguiar, C.; Mason, L.; Alves, R.A.; Daniel, J.R. Parents' Perceptions of Student Academic Motivation During the COVID-19 Lockdown: A Cross-Country Comparison. Front. Psychol. 2020, 11, 592670. [CrossRef] [PubMed]

21. Mooney, C.; Becker, B.A. Investigating the Impact of the COVID-19 Pandemic on Computing Students' Sense of Belonging. In Proceedings of the 52nd ACM Technical Symposium on Computer Science Education (SIGCSE '21), Virtual Event, USA, 13-20 March 2021. [CrossRef]

22. Markel, J.M.; Guo, P.J. Designing the Future of Experiential Learning Environments for a Post-COVID World: A Preliminary Case Study. In Proceedings of the Symposium on the New Future of Work, Virtual, 3-5 August 2020.

23. Stebleton, M.J.; Soria, K.M.; Huesman, R.L.; Torres, V. Recent immigrant students at research universities: The relationship between campus climate and sense of belonging. J. Coll. Stud. Dev. 2014, 55, 196-202. [CrossRef]

24. Mooney, C.; Becker, B.A. Sense of Belonging: The intersectionality of self-identified minority status and gender in undergraduate computer science students. U. K. Irel. Comput. Educ. Res. Conf. 2020, 20, 24-30. [CrossRef]

25. Oyedotun, T.D. Sudden change of pedagogy in education driven by COVID-19: Perspectives and evaluation from a developing country. Res. Glob. 2020, 2, 100029. [CrossRef]

26. Rodríguez-Marín, J.; Pastor, M.Á.; López-Roig, S. Afrontamiento, apoyo social, calidad de vida y enfermedad. Psicothema 1993, 5, 349-372.

27. Bernardo, A.-B.; Tuero, E.; Cervero, A.; Dobarro, A.; Galve, C. Bullying and cyberbullying: Variables that influence university dropout. Comunicar 2020, 28, 63-72. [CrossRef]

28. Orcasita, L.T.; Uribe, A. La importancia del apoyo social en el bienestar de los adolescentes. Psychol. Av. Discip. 2010, 4, 69-82. [CrossRef]

29. Fernández-Lasarte, O.; Vasco, U.D.P.; Goñi, E.; Camino, I.; Ramos-Díaz, E. Apoyo social percibido e implicación escolar del alumnado de educación secundaria. Perceived social support and school engagement in secondary students. Rev. Española Pedagog. 2019, 77, 123-141. [CrossRef]

30. Ensel, W.M.; Lin, N. The life stress paradigm and psychological distress. J. Health Soc. Behav. 1991, 32, 321. [CrossRef] [PubMed]

31. Davidson, C.; Wilson, K. Reassessing tinto's concepts of social and academic integration in student retention. J. Coll. Stud. Retent. Res. Theory Pract. 2013, 15, 329-346. [CrossRef]

32. Instituto Internacional para la Educación Superior en América Latina y el Caribe. COVID-19 y Educación Superior: De los Efectos Inmediatos al día Después. Análisis de Impactos, Respuestas Políticas y Recomendaciones; UNESCO: Caracas, Venezuela, 2020. 
33. Cacioppo, J.T.; Hawkley, L.C. Perceived social isolation and cognition. Trends Cogn. Sci. 2009, 13, 447-454. [CrossRef]

34. Perlman, D.; Peplau, L.A. Toward a social psychology of loneliness. In Personal Relationships: Relationships in Disorder, 1st ed.; Academic Press: London, UK, 1981; pp. 31-56.

35. Ali, A.; Smith, D.T. Comparing social isolation effects on students attrition in online versus face-to-face courses in computer literacy. Issues Inf. Sci. Inf. Technol. 2015, 12, 11-20. [CrossRef]

36. Peltzer, K.; Pengpid, S. Loneliness: Its correlates and associations with health risk behaviours among university students in 25 countries. J. Psychol. Afr. 2017, 27, 247-255. [CrossRef]

37. López-Angulo, Y.; Pérez-Villalobos, M.V.; Cobo-Rendón, R.C.; Díaz-Mujica, A.E. Apoyo social, sexo y área del conocimiento en el rendimiento académico autopercibido de estudiantes universitarios chilenos. Form. Univ. 2020, 13, 11-18. [CrossRef]

38. Glaría, R.; Carmona, L.; Martín, S.; Pérez, C.; Ponce, P. Burnout y engagement académico en fonoaudiología. Investig. En Educ. Méd. 2016, 5, 17-23. [CrossRef]

39. Bustamante, D.M.; Alvarado, O.S. Apoyo social: Uso del concepto en enfermería. Horiz. Enferm. 2016, 27, 32-40. [CrossRef]

40. Anistranski, J.A.; Brown, B.B. A Little Help from Their Friends? How Social Factors Relate to Students' Sense of Belonging at a Large Public University. J. Coll. Stud. Retent. Res. Theory Pract. 2021, 1-21. [CrossRef]

41. Brooms, D.R. Helping us think about ourselves: Black males' sense of belonging through connections and relationships with faculty in college. Int. J. Qual. Stud. Educ. 2019, 33, 921-938. [CrossRef]

42. Choi, S.; Weng, S.; Park, H.; Lewis, J.; Harwood, S.A.; Mendenhall, R.; Huntt, M.B. Sense of Belonging, Racial Microaggressions, and Depressive Symptoms among Students of Asian Descent in the United States. Smith Coll. Stud. Soc. Work. 2021, 91, 115-141. [CrossRef]

43. Dueñas, M.; Gloria, A.M. ¡Pertenecemos y tenemos importancia aquí! Exploring Sense of Belonging and Mattering for FirstGeneration and Continuing-Generation Latinx Undergraduates. Hisp. J. Behav. Sci. 2020, 42, 95-116. [CrossRef]

44. Whitten, D.; James, A.; Roberts, C. Factors That Contribute to a Sense of Belonging in Business Students on a Small 4-Year Public Commuter Campus in the Midwest. J. Coll. Stud. Retent. Res. Theory Pract. 2017, 22, 99-117. [CrossRef]

45. Garza, T.; Huerta, M.; García, H.A.; Lau, J. Exploring Sense of Belonging, Socioacademic Integrative Moments, and Learning Communities Related to ELs' Persistence Based on Reenrollment Decisions in Community Colleges. Community Coll. Rev. 2020, 49, 30-51. [CrossRef]

46. Itzhaki, Y. The Different Role of Mentor Support along the High-School Dropout Process. Youth Soc. 2018, 51, 981-1008. [CrossRef]

47. Gilardi, S.; Guglielmetti, C. University Life of Non-Traditional Students: Engagement Styles and Impact on Attrition. J. High. Educ. 2011, 82, 33-53. [CrossRef]

48. Pérez, M.; Cobo, R.; Matos, L.; Hernández, H.; Del Valle, M.; Díaz-Mujica, A. Variables cognitivo-motivacionales como predictoras del ajuste a la vida universitaria y la intención de abandonar los estudios en estudiantes de primer año. In Proceedings of the VII Conferencia Latinoamericana sobre el Abandono en la Enseñanza Superior (CLABES), Córdoba, Argentina, 15-17 November 2017.

49. Syed, N.K.; Syed, M.H.; Meraya, A.M.; Albarraq, A.A.; Al-Kasim, M.A.; Alqahtani, S.; Makeen, H.A.; Yasmeen, A.; Banji, O.J.F.; Elnaem, M.H. The association of dietary behaviors and practices with overweight and obesity parameters among Saudi university students. PLOS ONE 2020, 15, e0238458. [CrossRef]

50. Fernández, M.; Álvarez, J.; Ávalos, I.; Cuevas, M.; Barros, C.; Díaz, F.; González-Castellón, E.; González-González, D.; HernándezFernández, A.; Ibañez, P.; et al. Evaluation of the Emotional and Cognitive Regulation of Young People in a Lockdown Situation Due to the COVID-19 Pandemic. Front. Psychol. 2020, 11, 565503. [CrossRef]

51. Abdalellah, O.M.; Basin, A.K.; Abdul, N.; Vigil, J.V. Emergency remote teaching during Coronavirus pandemic: The current trend and future directive at Middle East College Oman. Innov. Infrastruct. Solut. 2020, 5, 4-11. [CrossRef]

52. Barrera, J.; Tovar-Torres, C.; Daza, J.; Polanco, J. Perception of virtual university education in the COVID-19. Rev. Iber. Sist. Tecnol. Inf. 2020, 31, 297-308.

53. Galvin, J.; Evans, M.S.; Nelson, K.; Richards, G.; Mavritsaki, E.; Giovazolias, T.; Koutra, K.; Mellor, B.; Zurlo, M.C.; Smith, A.P.; et al. Technostress, Coping, and anxious and depressive symptomatology in university students during the COVID-19 pandemic. Eur. J. Psychol. 2021; in press. [CrossRef]

54. Marques, B.; Marques, R.; Reis, R. Student's social vulnerability in distance learning in COVID-19 times. In Proceedings of the 14th IADIS International Conference E-Learning, Lisbon, Portugal, 12 July 2020.

55. Tahir, M.; Gökalp, E.; Nurcan, E. ICT-Based distance higher education: A necessity during the era of COVID-19 outbreak. In Emerging Technologies during the Era of COVID-19 Pandemic, 1st ed.; Arpaci, I., Al-Emran, M., Al-Sharafi, M.A., Marques, G., Eds.; Springer International Publishing: Cham, Switzerland, 2021; pp. 365-385.

56. Al Rawashdeh, A.Z.; Mohammed, E.Y.; Al Arab, A.R.; Alara, M.; Al-Rawashdeh, B. Advantages and Disadvantages of Using e-Learning in University Education: Analyzing Students' Perspectives. Electron. J. e-Learn. 2021, 19, 107-117. [CrossRef]

57. Ishmuhametov, I.; Kuzmenko, L. The Study of Students' Opinion on Learning Online in the Self-Isolation Period. Reliab. Stat. Transp. Commun. 2021, 195, 857-867. [CrossRef]

58. González-Tovar, M.; Hernández-Rodríguez, S. COVID-19 and Emotional Variables in a Sample of Chileans. Front. Psychol. 2021, 12, 615268. [CrossRef] [PubMed]

59. Scotta, A.V.; Cortez, M.V.; Miranda, A.R. Insomnia is associated with worry, cognitive avoidance and low academic engagement in Argentinian university students during the COVID-19 social isolation. Psychol. Health Med. 2020, 1-16. [CrossRef] 
60. Tinajero, C.; Martínez-López, Z.; Rodríguez, M.S.; Páramo, M.F. Perceived social support as a predictor of academic success in Spanish university students. An. de Psicol. 2019, 36, 134-142. [CrossRef]

61. Mercado, A.; Hernández, A.V. El proceso de construcción de la identidad colectiva. Convergencia 2010, 53, $229-251$.

62. Cole, D.; Newman, C.B.; Hypolite, L.I. Sense of Belonging and Mattering Among Two Cohorts of First-Year Students Participating in a Comprehensive College Transition Program. Am. Behav. Sci. 2019, 64, 276-297. [CrossRef]

63. Drezner, N.D.; Pizmony-Levy, O. I Belong, Therefore, I Give? The Impact of Sense of Belonging on Graduate Student Alumni Engagement. Nonprofit Volunt. Sect. Q. 2020, 50, 753-777. [CrossRef]

64. Gillen-O'Neel, C. Sense of Belonging and Student Engagement: A Daily Study of First- and Continuing-Generation College Students. Res. High. Educ. 2019, 62, 45-71. [CrossRef]

65. Holloway-Friesen, H. The Role of Mentoring on Hispanic Graduate Students' Sense of Belonging and Academic Self-Efficacy. J. Hisp. High. Educ. 2019, 20, 46-58. [CrossRef]

66. Won, S.; Hensley, L.C.; Wolters, C.A. Brief Research Report: Sense of Belonging and Academic Help-Seeking as Self-Regulated Learning. J. Exp. Educ. 2019, 89, 112-124. [CrossRef]

67. Tinto, V. Through the Eyes of Students. J. Coll. Stud. Retent. Res. Theory Pract. 2015, 19, 254-269. [CrossRef]

68. Baumeister, R.F.; Leary, M.R. The need to belong: Desire for interpersonal attachments as a fundamental human motivation Psychol. Bull. 1995, 117, 497-529. [CrossRef]

69. Torres, J.B.; Solberg, V. Role of Self-Efficacy, Stress, Social Integration, and Family Support in Latino College Student Persistence and Health. J. Vocat. Behav. 2001, 59, 53-63. [CrossRef]

70. Capello, H. La identidad universitaria. La construcción del concepto. Rev. Int. Cienc. Soc. y Humanid. 2015, 25, 33-53.

71. Boros, S.; Curseu, P.L. To be or not to be ... identified. Explorations of students'(dis)identification in a Romanian university. Psihol. Resur. Um. 2012, 10, 57-69.

72. Sedgwick, M.; Rougeau, J. Points of tension: A qualitative descriptive study of significant events that influence undergraduate nursing students' sense of belonging. Rural Remote Health 2010, 10, 1569. [CrossRef] [PubMed]

73. Maluenda-Albornoz, J.; López-Angulo, Y.; Varas-Contreras, M.; Bernardo, A.B.; Díaz-Mujica, A.; Moraga, F. Predictores psicosociales de la intención de abandono en estudiantes de ingeniería chilenos. In Proceedings of the 9th Conferencia Latinoamericana Sobre Abandono en Educación Superior CLABES, Bogotá, Colombia, 13-15 November 2019.

74. Wilkins, S.; Butt, M.M.; Kratochvil, D.; Balakrishnan, M. Studies in higher education the effects of social identification and organizational identification on student commitment, achievement and satisfaction in higher education. Stud. High. Educ. 2015, 41, 2232-2252. [CrossRef]

75. Di Battista, S.; Pivetti, M.; Berti, C. Engagement in the university context: Exploring the role of a sense of justice and social identification. Soc. Psychol. Educ. 2014, 17, 471-490. [CrossRef]

76. Capone, V.; Caso, D.; Donizzetti, A.; Procentese, F. University Student Mental Well-Being during COVID-19 Outbreak: What Are the Relationships between Information Seeking, Perceived Risk and Personal Resources Related to the Academic Context? Sustainability 2020, 12, 7039. [CrossRef]

77. Gopalan, M.; Brady, S.T. College Students' Sense of Belonging: A National Perspective. Educ. Res. 2019, 49, 134-137. [CrossRef]

78. Bettencourt, G.M. "I Belong Because It Wasn't Made for Me": Understanding Working-Class Students' Sense of Belonging on Campus. J. High. Educ. 2021, 92, 760-783. [CrossRef]

79. LaCosse, J.; Murphy, M.C.; Garcia, J.A.; Zirkel, S. The role of STEM professors' mindset beliefs on students' anticipated psychological experiences and course interest. J. Educ. Psychol. 2021, 113, 949-971. [CrossRef]

80. Moore, M.Z. Fostering a Sense of Belonging Using a Multicontext Approach. J. Coll. Stud. Retent. Res. Theory Pract. 2020, 1-18. [CrossRef]

81. Jiménez, M. Competencia social: Intervención preventiva en la escuela. Infanc. y Soc. 2000, 24, 21-48.

82. Catalán, X.; Santelices, M.V. Rendimiento académico de estudiantes de distinto nivel socioeconómico en universidades: El caso de la Pontificia Universidad Católica de Chile. Calid. en la Educ. 2014, 40, 21-52. [CrossRef]

83. Gallegos, J.A.; Campos, N.A.; Canales, K.A. Factores Determinantes en la Deserción Universitaria. Caso Facultad de Ciencias Económicas y Administrativas de la Universidad Católica de la Santísima Concepción (Chile). Form. Univ. 2018, 11, 11-18 [CrossRef]

84. Vergara-Díaz, G.; López, H.P. Relación del desempeño académico de estudiantes de primer año de universidad en Chile y los instrumentos de selección para su ingreso. Rev. Educ. 2017, 41, 2. [CrossRef]

85. Tinto, V. Completing College. Rethinking Institutional Action, 1st ed.; The University of Chicago Press: Chicago, IL, USA, 2012.

86. De Oviedo, U.; Cerezo, R.; Rodríguez-Muñiz, L.J.; Tuero, E.; Esteban, M. Predicción del abandono universitario: Variables explicativas y medidas de prevención. Rev. Fuentes 2015, 16, 63-84. [CrossRef]

87. García, M.E.; Gutiérrez, A.B.B.; Herrero, E.T.; Menéndez, R.C.; Pérez, J.C.N. El contexto sí importa: Identificación de relaciones entre el abandono de titulación y variables contextuales. Eur. J. Educ. Psychol. 2016, 9, 79-88. [CrossRef]

88. Tudela, H.E. Una aproximación teórica to the college student Drop Out. Rev. Digit. de Investig. en Docencia Univ. 2014, 8, 59-74. [CrossRef]

89. Maroco, J.; Maroco, A.L.; Campos, J.A.D.B.; Fredricks, J.A. University student's engagement: Development of the University Student Engagement Inventory (USEI). Psicol. Reflexão e Crítica 2016, 29, 21. [CrossRef] 
90. Fredricks, J.; Reschly, A.; Christenson, S. Handbook of Student Engagement Interventions. Working with Disengaged Students, 1st ed.; London Academic Press: London, UK, 2019.

91. Antúnez, Á.; Cervero, A.; Solano, P.; Bernardo, I.; Carbajal, R. Engagement: A new perspective for reducing dropout through self-regulation. In Factors Affecting Academic Perfomance, 1st ed.; González-Pienda, J.A., Bernardo, A.B., Núñez, J.C., Rodríguez, C., Eds.; Nova Science Publishers: New York, NY, USA, 2017; pp. 25-46.

92. Ryan, R.M.; Deci, E.L. Self-Determination Theory. Basic Psychological Needs in Motivation, Development, and Wellness, 1st ed.; Guilford Press: New York, NY, USA, 2018.

93. Lerdpornkulrat, T.; Koul, R.; Poondej, C. Relationship between perceptions of classroom climate and institutional goal structures and student motivation, engagement and intention to persist in college. J. Furth. High. Educ. 2016, 42, 102-115. [CrossRef]

94. Truta, C.; Parv, L.; Topala, I. Academic Engagement and Intention to Drop Out: Levers for Sustainability in Higher Education. Sustainability 2018, 10, 4637. [CrossRef]

95. Perets, E.A.; Chabeda, D.; Gong, A.Z.; Huang, X.; Fung, T.S.; Ng, K.Y.; Bathgate, M.; Yan, E.C.Y. Impact of the Emergency Transition to Remote Teaching on Student Engagement in a Non-STEM Undergraduate Chemistry Course in the Time of COVID-19. J. Chem. Educ. 2020, 97, 2439-2447. [CrossRef]

96. Daniels, L.M.; Goegan, L.D.; Parker, P.C. The impact of COVID-19 triggered changes to instruction and assessment on university students' self-reported motivation, engagement and perceptions. Soc. Psychol. Educ. 2021, 24, 299-318. [CrossRef]

97. Pasion, R.; Paiva, T.O.; Fernandes, C.; Barbosa, F. The AGE Effect on Protective Behaviors during the COVID-19 Outbreak: Sociodemographic, Perceptions and Psychological Accounts. Front. Psychol. 2020, 11, 561785. [CrossRef]

98. Marôco, J.; Assunção, H.; Harju-Luukkainen, H.; Lin, S.-W.; Sit, P.-S.; Cheung, K.-C.; Maloa, B.; Ilic, I.S.; Smith, T.J.; Campos, J.A.D.B. Predictors of academic efficacy and dropout intention in university students: Can engagement suppress burnout? PLoS ONE 2020, 15, e0239816. [CrossRef]

99. Yañez, R.; Perez, M.V.; Ahumada, L. Adaptación y validación de una escala de identificación organizacional con centros de estudio. Paideia 2006, 41, 65-76.

100. Maluenda-Albornoz, J.; Varas, M.; Bernardo, A.B.; Díaz-Mujica, A. Adaptación y evaluación psicométrica de la escala de identificación organizacional con centros educativos en estudiantes de ingeniería chilenos. Cuad. Pedagog. Univ. 2022; accepted.

101. Díaz-Mujica, A. FONDECYT Project $N^{\circ} 1161502$, Modelo Explicativo de la Permanencia y el Abandono de los Estudios Universitarios, Basado en Procesos Cognitivo-Motivacionales; ANID: Santiago, Chile, 2019. Available online: http://repositorio.conicyt.cl/handle/ 10533/116333 (accessed on 1 December 2020).

102. Russell, D. UCLA Loneliness Scale (Version 3): Reliability, Validity, and Factor Structure. J. Pers. Assess. 1996, 66, 20-40. [CrossRef]

103. Kline, R.B. Principles and Practice of Structural Equation Modelling, 4th ed.; Guilford Press: New York, NY, USA, 2011.

104. Muthén, L.K.; Muthén, B.O. MPLUS User's Guide, 7th ed.; Muthén \& Muthen: Salt Lake City, USA, 2012.

105. Hair, J.; Sarstedt, M.; Hopkins, L.; Kuppelwieser, V.G. Partial least squares structural equation modeling (PLS-SEM): An emerging tool in business research. Eur. Bus. Rev. 2014, 26, 106-121. [CrossRef]

106. Hair, J.; Black, W.; Babin, B.; Anderson, R. Multivariate Data Analysis, 7th ed.; Pearson: London, UK, 2014.

107. Ventura-León, J.; Caycho-Rodríguez, T. El coeficiente omega: Un método alternativo para la estimación de la confiabilidad. Rev. Latinoam. Cienc. Soc. Niñez y Juv. 2017, 15, 625-627.

108. Fernandez-Lasarte, O.; Ramos-Diaz, E.; Palacios, E.G.; Rodríguez-Fernández, A. Estudio comparativo entre educación superior y media: Efecto del apoyo social percibido, el autoconcepto y la inteligencia emocional en el rendimiento académico. Educ. XX1 2019, 22, 165-185. [CrossRef]

109. Rautanen, P.; Soini, T.; Pietarinen, J.; Pyhältö, K. Primary school students' perceived social support in relation to study engagement. Eur. J. Psychol. Educ. 2020, 36, 653-672. [CrossRef]

110. Zurlo, M.C.; Della Volta, M.F.C.; Vallone, F. COVID-19 Student Stress Questionnaire: Development and Validation of a Questionnaire to Evaluate Students' Stressors Related to the Coronavirus Pandemic Lockdown. Front. Psychol. 2020, 11, 576758. [CrossRef]

111. Álvarez-Pérez, P.R.; López-Aguilar, D. Estudios sobre deserción académica y medidas orientadoras de la prevención en la Universidad de La Laguna (España). Rev. Paradig. 2017, 38, 48-71. [CrossRef]

112. González-Gamarra, D.O.; Charry, J.M. Engagement en el estudio, inteligencia emocional y rendimiento académico en estudiantes de la escuela profesional de Ingeniería Forestal de la UNSAAC. Rev. CEPROSIMAD 2018, 6, 6-17.

113. Sträßer, R. Learners' engagement in mathematics-theories, frameworks and results. Math. Educ. Res. J. 2017, 29, 255-259. [CrossRef]

114. Fourie, C.M. Risk factors associated with first-year students' intention to drop out from a university in South Africa. J. Furth High. Educ. 2018, 1-15. [CrossRef]

115. Sandoval-Palis, I.; Naranjo, D.; Vidal, J.; Gilar-Corbi, R. Early Dropout Prediction Model: A Case Study of University Leveling Course Students. Sustainability 2020, 12, 9314. [CrossRef]

116. Gutiérrez, M.R.D.B.; Gil Flores, J.; González, A.J.G. Variables psicosociales y rendimiento académico asociados al optimismo en estudiantes universitarios españoles de nuevo ingreso. Acta Colomb. Psicol. 2019, 22, 152-174. [CrossRef] 